\title{
The impact of diversification on cash to cash flow sensitivity evidence from Pakistani manufacturing firms
}

\author{
Samad Shahbaz
}

\begin{abstract}
This paper contributes that existing knowledgeby augmented the model proposed by alameda et al with the variable of cash flow volatility and diversification. The panel data analysis revealed that Pakistani firms are highly dependent on cash and hold more cash out of their operational cash flow. Further cash flow volatility has proven to be insignificant contributor of higher cash flow by Pakistani firms in the presence of diversification. The interactive dummy of diversification exhibits a negative significant coefficient indicating that diversified firms hold less cash out of their cash flow and thus do not need huge cash holding.
\end{abstract}

\section{Introduction}

The liquidity preference approach in Keynesian theory deals with the demand of liquid assets such as cash. According to Keynesian theory, a lot of attention is paid to the precautionary motive, which studies the behavior of people when it comes to saving resources such as money. The goal of this theory is to find the cash balance that can further be divided into active cash balance and idle cash balance. There were two other motives that Keynes identified when he studied the motives which drive firms to hold cash. When a firm holds cash, it doesn't need to access external sources of finance to complete transactions. Secondly, the precautionary motives helps in saving money that can be useful when unforeseen circumstances take place.

According to Fisher separation theorem, the main objective of any firm is to maximize its present value. There are three opinions on investment that counter this theorem. The first one is how the investment decisions of a firm are different from those of the owner. The second is the differences in financing decisions of the firm and its owners. And the third is that there is not much befit of using mix methods to finance firm investments. Therefore, it can be said that the available market opportunities determine how the business is run. The firms finance and dividend payment decisions aren't significant determinants of how a firm is run. The strength of the impact of cash flow volatility on cash holdings is determined by the financial constraints of the firm.

Cash flows are also affected by investment opportunities. An inverse correlation was determined between investment and precautionary demand, in a study conducted by Duchin (2007). Cash held with the precautionary motive can be used to provide a firm with liquidity and help a firm during uncertain situations, especially those related to external finance.

\section{Literature review}

Cash is the most liquid asset and Keynesian theory deals with the demand of liquid assets such as cash in its liquidity preference approach. Cash management can be divided into three motives which include Speculative motive, Precautionary motive, and Transactionmotive. These three motives are the factors that affect the demand for cash. In Keynesian theory, precautionary motive is given a lot of consideration and is related to the desire to save, resources or money. The idea it to obtain cash in a reliable but less costly manner so that it can be reimbursed conveniently when the time comes. Nguyen (2005) found that the cash balance held with a precautionary motive reduced the instability offirm's earnings, which is also one way of measuring risk of a firm. The aim of the theory is to reach the cash a balance which will be divided into two kinds even further: the active and idle cash balances.

The active cash balance is implied for demand for the precautionary and transaction motive because the demand for cash under these motives is very active. Speculative motive lies under idle cash balance because this cash is only needed under uncertain circumstances and the demand for cash is not high. According to Keynes, as opposed to Fisher, the demand for money is not the amount of money that people are currently holding. Instead, it is the amount of money that people want to hold.

The Fisher SeparationTheorem is based on the main objective of a firms is to maximize its PVirrespective of owner preferences. There are three counter opinions that this theorem faces. The first one is about how the investment decisions of a firm and the owners differ. Similarly, the second counter opinion is about the difference in financing decisions of the owners and the firm itself. And the last is that mix methods of financing are of not much use when it comes to investments for a firm. Therefore, it can be concluded that the running of the firm depends less on its finance and dividend payment decisions, and more on the market opportunities available. 
The Fisher theorem complements the perfect market concept very well because in that case, managers are more focused on designing investment strategies that increase the profits of the firm. It was observed in another study investment and consumption decisions of consumers remain independent in perfect capital markets.

The decisions for optimumcash holdings and short term investments are made founded on the exchange between cash holdings and short term investments. It was predicted by Kim et al. (1998) that firms that are financially unconstrained and hold extra cash earn less marginal returns on their short term investment as compared to the risk free rate. Therefore, such a firm tends to hold more amounts of cash, while financially constrained firms hold no cash.

Low information asymmetry is necessary for high firm value. The opinion of Opler et al. (1999) was that cash flow and the volatility of cash flow have large impacts on the amount of cash a firm holds. It was found that more cash holdings result from high cash flows. In the same manner, more cash holdings are present in firms which have more cash flow volatility, because of the precautionary motive.

It was indicated in the work of Almeida et al. (2004) that constrained firms tend to exhibit more cash to cash flow sensitivity when compared to unconstrained firms. Acharya elaborated the study further in 2006 and added that investment opportunities as a factor that also affects cash flow. The correlation between the two was found to be inverse. The relation was then taken to the money demand perspective and according to the results better investments take place when external funds are accessed but at the same time, the precautionary motive for holding cash is for very minute value. However, when risks of operating and investing are high, the precautionary demand for holding cash plays an important role in saving cash. Asymmetric information also plays a significant role in determining cash holdings.

The elements of corporate cash holdings were studied by Ferreira and Vilela (2004) and it was found that more investment opportunities led to more cash being held and hence more cash flows. However, cash holdings are affected negatively by firm size, leverage and liquidity of assets. Dittmar (2003) studied how important corporate governance was in defining the cash flows of a firm. Hofmann (2006) studied how nonfinancial firms are affected by corporate cash holdings. He proposed that factors that determine corporate cash holdings include cash flow variability, dividend payments and growth opportunities. It was found that dividend payments are inversely proportional to holdings of cash.

\section{Sample:}

\section{Methodology}

Our sample out of 150 firms includes 24 firms because that meet regarding criteria and the data of the different variables used in the study is available throughout the sample period. These 24 firms were taken for research paper was also listed in Karachi stock exchange (KSE-100index) in Pakistan.

Data:

The data for the study obtained from analyzed balance sheet published by SBP and annual report of sample firms. The estimation period from 2006 to 2010 the period is rohbust because during this period Pakistani economy has experienced almost every face of economic cycle.

\section{Regression Model:}

For the study we will assumption Almedia et al. (2004) model with Diversification variables. The base line regression model as follow:

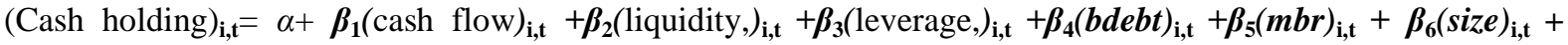
$\beta_{7}(\text { volt })_{\mathrm{i}, \mathrm{t}}+\beta_{8}(\text { div })_{\mathrm{i}, \mathrm{t}}+\beta_{9}(\text { dver })_{\mathrm{i}, \mathrm{t}}++\beta_{10}(\operatorname{dvercf})_{\mathrm{i}, \mathrm{t}} E_{\mathrm{i}, \mathrm{t}}$

Where, bdebt $=$ bank debt, $\mathrm{mbr}=$ market to book ratio, volt $=$ variability, div $=$ dividend, dver $=$ diversification, dvercf $=$ diversification cashflow, $\mathrm{e}=$ error term

\section{Variable Procedure:}

The cash holding is measured by cash to cash equivalents divided total assets minus cash. "Cash flow" is the sum of earnings before interest tax and depreciation divided by total assets minus cash. "Liquidity" is the amount of current asset minus current liabilities and cash dividing by total assets. "Leverage" is the sum of total debts divide by total assets. The "bank debt" is the difference of total bank borrowings from total debt. The "mbr" is the ratio of book value of total assets minus the book value of total equity plus the market value of equity to book value of assets. "Size" the size of the firms as taken control variable, size is the natural log of total assets prices from 2006 to 2010. "Dividend" the total amount of dividend divided by total assets minus total cash. For "diversification" the diversified firms are equals to one and singular firms are equals to zero. Dummy "diversification cash flow" (dvercf) it is the interacted dummy of diversification multiplied by cash flow. 
Panel Data Regression Model:

We will estimate common effect model. The Cf model will be:

\section{Common Effect Model:}

The simple assumption of this model is homogeneity of cross-sectional units. We estimate the following common effect model:

$(\text { Cash holding })_{\mathrm{i}, \mathrm{t}}=\alpha+\boldsymbol{\beta}_{1}(\boldsymbol{c f})_{\mathrm{i}, \mathrm{t}}+\boldsymbol{\beta}_{2}(\text { liq })_{\mathrm{i}, \mathrm{t}}+\boldsymbol{\beta}_{3}(\text { lev })_{\mathrm{i}, \mathrm{t}}+\boldsymbol{\beta}_{4}(\boldsymbol{b d e b t})_{\mathrm{i}, \mathrm{t}}+\boldsymbol{\beta}_{5}(\boldsymbol{m b r})_{\mathrm{i}, \mathrm{t}}+\boldsymbol{\beta}_{6}(\operatorname{size})_{\mathrm{i}, \mathrm{t}}+\boldsymbol{\beta}_{7}(\boldsymbol{v o l t})_{\mathrm{i}, \mathrm{t}}+\boldsymbol{\beta}_{\mathbf{8}}(\operatorname{div})_{\mathrm{i}, \mathrm{t}}$ $+\beta_{9}(d v e r)_{\mathrm{i}, \mathrm{t}}++\beta_{10}(\operatorname{dvercf})_{\mathrm{i}, \mathrm{t}} E_{\mathrm{i}, \mathrm{t}}$

However due to the serious disadvantage of simplistic homogeneity, we might not be able to produce generalizable results using common effect model.

\section{FE Model:}

FE isa commandingpane data estimation technique it is for heterogeneity by incorporating a unique interest of every cross-sectional unit. The following fixed effect model will:

$(\text { cash holding })_{\mathrm{i}, \mathrm{t}}=\alpha+\boldsymbol{\beta}_{1}(\boldsymbol{c f})_{\mathrm{i}, \mathrm{t}}+\boldsymbol{\beta}_{2}(\text { liq })_{\mathrm{i}, \mathrm{t}}+\boldsymbol{\beta}_{3}(\text { lev })_{\mathrm{i}, \mathrm{t}}+\boldsymbol{\beta}_{4}(\boldsymbol{b d e b t})_{\mathrm{i}, \mathrm{t}}+\boldsymbol{\beta}_{5}(\boldsymbol{m b r})_{\mathrm{i}, \mathrm{t}}+\boldsymbol{\beta}_{6}(\operatorname{size})_{\mathrm{i}, \mathrm{t}}+\boldsymbol{\beta}_{7}(\boldsymbol{v o l t})_{\mathrm{i}, \mathrm{t}}+\boldsymbol{\beta}_{8}(\text { div })_{\mathrm{i}, \mathrm{t}}$ $+\beta_{9}(d v e r)_{\mathrm{i}, \mathrm{t}}++\beta_{10}(\operatorname{dvercf})_{\mathrm{i}, \mathrm{t}} E_{\mathrm{i}, \mathrm{t}}$

\section{Heteroskedasticity Test:}

Sometimes due to the large observation and limited time of period, the problem of heteroskedasticity occurs. In order to deduct the data where is heteroskedasticity or not, we will conduct Bausch/Phagan test for heteroskedasticity under the following hypothesis:

Ho: The data is not heteroskedasticity.

H1: The data is heteroskedasticity

The $\mathrm{P}$ value of 0.05 or less will indicate that data is having the problem is heteroskedasticity. In this case we will conduct the test rohbust standard error.

\section{Housman Tests:}

Sometimes fixed effect and common effect model may give us difference result thus in order to select the best model that can provide us with rohbust and generalizable results, we will conduct Housman test under the following hypothesis:

H1: Fixed effect result is accepted.

Ho: Common effect result is accepted.

Table 1

\section{Results and Discussion:}

\begin{tabular}{r|rrrrr} 
sum cahhold cf liq lev bdebt mbr size volt div dver dvercf \\
Variable & Obs & Mean & Std. Dev. & Min & Max \\
\hline cahhold & 110 & .0549993 & .0720852 & .0003108 & .3647835 \\
cf & 110 & .1632431 & .1676837 & -.2058165 & .591127 \\
liq & 110 & .0995009 & .2386835 & -.5517797 & .8064721 \\
lev & 110 & .1395449 & .1631584 & 0 & .6367394 \\
bdebt & 110 & .7021206 & .4573614 & 0 & 1 \\
\hline mbr & 110 & 1.8998 & 3.137175 & .1163003 & 22.26874 \\
size & 110 & 16.81859 & 1.074216 & 14.16245 & 19.24866 \\
volt & 110 & .0212379 & .003672 & .0079096 & .0279255 \\
div & 110 & .0690524 & .1984424 & 0 & 1.964273 \\
dver & 110 & .5454545 & .5002085 & 0 & 1 \\
\hline dvercf & 110 & .111044 & .1682441 & -.2058165 & .591127
\end{tabular}

Descriptive statistics indicates 110 firms' observations for every variable of the study. The means scores of cash holding is $5 \%$ while cash flow is about $16 \%$. $6 \%$ of our firm's diversified and interactive dummy has a mean score of $11.1 \%$. The statistics shed like on the fact that when diversification interacts with Cash flow the relationship tends to be negative. 


\section{Correlation Matrix}

Table 2 represents the Correlation matrix use in the study

\begin{tabular}{|c|c|c|c|c|c|c|c|}
\hline & cahhold & $\operatorname{cf}$ & liq & lev & bdebt & $\mathrm{mbr}$ & size \\
\hline cahhold & 1.0000 & & & & & & \\
\hline cf & 0.2780 & 1.0000 & & & & & \\
\hline liq & 0.0237 & 0.3066 & 1.0000 & & & & \\
\hline lev & -0.2987 & -0.4009 & -0.3575 & 1.0000 & & & \\
\hline bdebt & -0.3110 & -0.4625 & -0.4374 & 0.4976 & 1.0000 & & \\
\hline $\mathrm{mbr}$ & 0.1141 & 0.4341 & -0.1563 & -0.1896 & 0.0043 & 1.0000 & \\
\hline size & -0.1420 & -0.1998 & -0.2046 & 0.2939 & 0.2335 & -0.1252 & 1.0000 \\
\hline volt & 0.1249 & 0.0002 & -0.0136 & -0.1351 & -0.1735 & 0.1191 & 0.1861 \\
\hline div & 0.0523 & 0.3975 & 0.1016 & -0.1875 & -0.2521 & 0.1410 & -0.1301 \\
\hline dver & 0.2247 & 0.2647 & -0.1179 & -0.0490 & -0.1161 & 0.2489 & 0.0166 \\
\hline \multirow[t]{2}{*}{ dvercf } & 0.1619 & 0.7960 & 0.1258 & -0.3148 & -0.3390 & 0.4893 & 0.0094 \\
\hline & volt & div & dver & dvercf & & & \\
\hline volt & 1.0000 & & & & & & \\
\hline div & -0.0153 & 1.0000 & & & & & \\
\hline dver & -0.0031 & 0.2342 & 1.0000 & & & & \\
\hline dvercf & -0.0385 & 0.4405 & 0.6053 & 1.0000 & & & \\
\hline
\end{tabular}

The correlation matrix indicates that there is no momentous correlation amount or independent variable, thus our model will not victim of multicollinearity.

\section{Regression Results}

We begin our analysis by estimating common effect model with standard errors. Appendix

\begin{tabular}{|c|c|c|c|c|c|c|}
\hline Source & ss & \multicolumn{2}{|c|}{ MS } & & \multirow{3}{*}{$\begin{array}{l}\text { Number of obs } \\
\text { F( } 10, \\
\text { Prob }>\text { F } \\
\text { R-squared } \\
\text { Adj R-squared } \\
\text { Root MSE }\end{array}$} & \multirow{3}{*}{$\begin{array}{r}110 \\
3.72 \\
0.0003 \\
0.2731 \\
0.1997 \\
.06449\end{array}$} \\
\hline $\begin{array}{r}\text { Model } \\
\text { Residual }\end{array}$ & $\begin{array}{r}.15468146 \\
.411712647\end{array}$ & $\begin{array}{l}.01 \\
.00\end{array}$ & $\begin{array}{l}68146 \\
58714\end{array}$ & & & \\
\hline Total & .566394107 & 109 & 96276 & & & \\
\hline cahhold & Coef. & std. Er & t & $P>|t|$ & [95 conf. & erval] \\
\hline cf & .2513686 & .0774823 & 3.24 & 0.002 & .0976269 & 4051103 \\
\hline liq & -.0524811 & .0315103 & -1.67 & 0.099 & -.1150044 & 0100421 \\
\hline lev & -.1030286 & .0475556 & -2.17 & 0.033 & -.1973893 & -.0086679 \\
\hline bdebt & -.0310564 & .0182796 & -1.70 & 0.092 & -.067327 & .0052143 \\
\hline $\mathrm{mbr}$ & .000434 & .0025878 & 0.17 & 0.867 & -.0047008 & .0055688 \\
\hline size & .0029114 & .00703 & 0.41 & 0.680 & -.0110376 & .0168604 \\
\hline volt & .4197883 & 1.877774 & 0.22 & 0.824 & -3.306123 & 4.1457 \\
\hline div & -.02217 & .0355017 & -0.62 & 0.534 & -.0926131 & .048273 \\
\hline dver & .0610548 & .0181619 & 3.36 & 0.001 & .0250176 & .097092 \\
\hline dvercf & -.2828785 & .0958726 & -2.95 & 0.004 & -.4731106 & -.0926464 \\
\hline - cons & -.003696 & .1142353 & -0.03 & 0.974 & -.2303638 & .2229717 \\
\hline
\end{tabular}

The result indicate that a positive significant for Cash flow, positive significant for diversification. The results however assume homogeneity of the cross sectional variable also we have not checked our data for heteroskedasticity. To test for heteroskedasticity we conducted heteroskedasticity test whose results are as follows

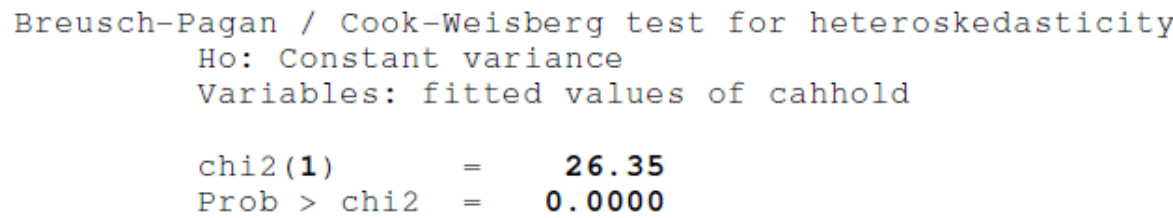

The heteroskedasticity test clearly indicates that our data is heteroskedasticity ( $\mathrm{P}$ value $0.00<0.05$ ). Thus from onwards we conduct all the test using robust standard errors. 
Table 3

Common effect

\begin{tabular}{|c|c|c|c|c|c|c|}
\hline cahhold & coef. & $\begin{array}{c}\text { Robust } \\
\text { std. Err. }\end{array}$ & t & $P>|t|$ & [95\% Conf. & Interval] \\
\hline $\mathrm{cf}$ & .2513686 & .1120895 & 2.24 & 0.027 & .0289587 & .4737785 \\
\hline liq & -.0524811 & .0313518 & -1.67 & 0.097 & -.11469 & .0097277 \\
\hline lev & -.1030286 & .0355805 & -2.90 & 0.005 & -.1736281 & -.0324291 \\
\hline bdebt & -.0310564 & .0218652 & -1.42 & 0.159 & -.0744416 & .0123289 \\
\hline $\mathrm{mbr}$ & .000434 & .0020651 & 0.21 & 0.834 & -.0036637 & .0045316 \\
\hline size & .0029114 & .0050813 & 0.57 & 0.568 & -.0071711 & .0129939 \\
\hline volt & .4197883 & 1.397227 & 0.30 & 0.764 & -2.352613 & 3.19219 \\
\hline div & -.02217 & .0247699 & -0.90 & 0.373 & -.071319 & .0269789 \\
\hline dver & .0610548 & .015406 & 3.96 & 0.000 & .0304861 & .0916236 \\
\hline
\end{tabular}

Fixed effect

\begin{tabular}{|c|c|c|c|c|c|c|}
\hline cahhold & coef. & $\begin{array}{l}\text { Robust } \\
\text { std. Err. }\end{array}$ & t & $P>|t|$ & [95\% Conf. & Interval] \\
\hline$c f$ & .4183672 & .1204366 & 3.47 & 0.001 & .1786442 & .6580903 \\
\hline $1 i q$ & -.0360644 & .0388121 & -0.93 & 0.356 & -.1133181 & .0411892 \\
\hline lev & .0036649 & .0453025 & 0.08 & 0.936 & -.0865074 & .0938373 \\
\hline bdebt & -.0160401 & .0161188 & -1.00 & 0.323 & -.0481237 & .0160435 \\
\hline mbr & .0047678 & .0015123 & 3.15 & 0.002 & .0017577 & .007778 \\
\hline size & -.0035123 & .0186539 & -0.19 & 0.851 & -.0406419 & .0336172 \\
\hline volt & 1.480007 & 9.436519 & 0.16 & 0.876 & -17.30291 & 20.26293 \\
\hline $\begin{array}{r}\text { div } \\
\text { dver }\end{array}$ & $\begin{array}{c}.0129033 \\
\text { (dropped) }\end{array}$ & .0179823 & 0.72 & 0.475 & -.0228895 & .0486961 \\
\hline dvercf & -.3272187 & .1735519 & -1.89 & 0.063 & -.6726652 & .0182278 \\
\hline _cons & .0550694 & .4558687 & 0.12 & 0.904 & -.8523146 & .9624534 \\
\hline
\end{tabular}

Random effect

\begin{tabular}{r|rrrrrr}
\hline \multirow{2}{*}{ cahhold } & Coef. & Robust \\
& Std. Err. & $z$ & P > |z| & [95\% Conf. Interval] \\
\hline cf & .3765656 & .1174358 & 3.21 & 0.001 & .1463958 & .6067355 \\
lev & -.0360679 & .0333078 & -1.08 & 0.279 & -.10135 & .0292143 \\
bdebt & -.0285635 & .0309025 & -0.92 & 0.355 & -.0891313 & .0320043 \\
mbr & -.0198201 & .0172667 & -1.15 & 0.251 & -.0536622 & .014022 \\
size & .0030723 & .0017095 & 1.80 & 0.072 & -.0002783 & .0064228 \\
volt & 1.057602 & 2.556218 & 0.41 & 0.679 & -.0132183 & .0178142 \\
div & .0027179 & .0137267 & 0.20 & 0.843 & -.0241859 & .0296216 \\
dver & .0587597 & .0262965 & 2.23 & 0.025 & .0072195 & .1102999 \\
dvercf & -.3413536 & .1430436 & -2.39 & 0.017 & -.621714 & -.0609933 \\
_cons & -.0462614 & .1403182 & -0.33 & 0.742 & -.3212801 & .2287573 \\
\hline
\end{tabular}

Table 3 indicates the result of common, fixed and random effect model will robust standard error. The variable of cash flow and diversification have positive significant impact on cash holdings, while the coefficient of leverage and diversification cash flow have negative significant on cash holdings. However as indicate earlier common effect model has over simplistic assumption thus its result cannot be generalized. The Fixed effect model carried under robust standard error indicates positive significant coefficient for cash flow and market book ratio, however the interactive dummy has insignificant impact on cash holding. The random effect model indicates a positive significant coefficient for cash flow and diversification and negative significant for interactive dummy diversification cash flow (Dvrcf).

The results shows that both FE and RF model has disagree on results. Therefore in order to select model for our study we will conduct random effect model whose results are given below. The houseman test reveals a $\mathrm{P}$ value of 0.995 that indicates that we will accept the result of RF model. The RF model indicates that cash flow has positive significant coefficient.

This result is aplacement with the results of Almedia et al. (2004). A positive momentous coefficient cash flow indicates that Pakistani firms hold more cash out of their operational cashflows. This heavy reliance on cash indicates that Pakistani firms use cash holdings for their investment and precautionary needs. This result is an alignment with the findings of Fazzari 1988 and can be safely said that Pakistani firms invest in positive NPV projects from their internal funds.

The coefficient for mean coefficient dummy is Positive and significant that indicates that diversified firms are also dependent on their cash holding. However the interactive dummy of diversification and cash holding indicates negative significant coefficient for cash holdings. This shows that diversified firms hold smaller amount cash from operational cash flows. 


\section{Conclusion}

In this research paper the result indicates that a positive significant coefficient for cash flow and diversification and negative significant for interactive dummy diversification cash flow. However the interactive dummy of diversification and cash holding indicates negative significant coefficient for cash holdings. The result shows that diversified firms hold less cash from operational cash flows. The results over all indicate that Pakistani firms are more cash reliant, they hold this cash for mainly two reasons that are precautionary and investment motives.. The reason for this is that they can obtain funds from markets at lower costs also they can obtain funds from sister organization and can invest in NPV projects.

\section{References}

[1]. Acharya, V., Almeida, H., (2006).Is cash negative debt? A hedging perspective on corporate financial policies. London Business School working paper.

[2]. Chang, K., \& Noorbakhsh, A. (2006). Corporate cash holdings, foreign direct investment and corporate governance. Global Finance Journal, 16, 302-316.

[3]. Dittmar, A., Mahrt-Smith, J., \& Servaes, H. (2003). International corporate governance and corporate cash holdings. Journal of Financial and Quantitative Analysis, 38, 111-133.

[4]. Duchin, R. (2007). Cash holdings and corporate diversification. Job Market Paper, University of Southern California.

[5]. Fazzari (1988). Financing constraints and corporate investment. Brookings Papers on Economic Activity.

[6]. Ferreira, M.A., \& Vilela, A.S. (2004). Why do firms hold cash? Evidence from EMU countries. European Financial Management, $10,295-319$

[7]. Han, S., \& Qiu, J. (2007). Corporate precautionary cash holdings. Journal of Corporate Finance, 13, 43-57.

[8]. Harford, J., Mansi, S.A.,\& Maxwell, W.F. (2005).Corporate governance and firm cash holdings. Working paper, University of Washington, Virginia Tech and University of Arizona.

[9]. Michelson, W.H., \&Patch, M.M. (2003). Do persistent large cash reserves hinder performance? Journal of Financial and Quantitative Analysis, 38, 275-294

[10]. Modigliani, F., \& Miller, M.H.(1958). The cost of capital, corporation finance and the theory of investment. American Economic Review, 48, 261-97.

[11]. Opler, T., Pinkowitz, L., Stulz, R., \&Williamson, R. (1999). The determinants and implications of corporate cash holdings. Journal of Financial Economics, 52, 3-46. 